Geomicrobiology Journal

January 2009 ; Volume 26, Issue 1 : Pages 31-43

http://dx.doi.org/10.1080/01490450802599284

(c) 2009 Taylor \& Francis
Archimer http://www.ifremer.fr/docelec/ Archive Institutionnelle de l'Ifremer

The original publication is available at http://www.tandf.co.uk/journals/

\title{
Archaeal Methane Cycling Communities Associated with Gassy Subsurface Sediments of Marennes-Oléron Bay (France)
}

\author{
Erwan G. Roussel ${ }^{a,{ }^{*}} ;$ Anne-Laure Sauvadet ${ }^{\mathrm{a}} ;$ Jonathan Allard ${ }^{\mathrm{b}} ;$ Carine Chaduteau ${ }^{\mathrm{c}} ;$ Pierre \\ Richard $^{\mathrm{b}}$; Marie-Anne Cambon Bonavita ${ }^{\mathrm{a}}$; Eric Chaumillon ${ }^{\mathrm{b}}$
}

\footnotetext{
a Laboratoire de Microbiologie des Environnements Extrêmes, Université de Bretagne Occidentale, CNRS, Institut Universitaire Européen de la Mer, Plouzané, France

${ }^{\mathrm{b}}$ La Rochelle University, La Rochelle, France

c Département Géosciences Marines, Plouzané, France
}

*: Corresponding author : E. Roussel, email address : RousselEG@cardiff.ac.uk

\begin{abstract}
:
In Marennes-Oleacuteron Bay, a macro-tidal bay located on the French Atlantic coast, kilometer-scale acoustic turbidity reveals an accumulation of free gas in the sediment. Large concentrations of organic matter and rapid sedimentation rates provide ideal settings for biogenic methane cycling. We integrate seismic, sedimentologic, biogeochemical and molecular genetic approaches to determine whether microbial methane cycling is involved in this process. Here we show that the acoustic turbidity upper boundary matched with X-ray facies displaying fissures with the highest methane concentrations, demonstrating the existence of methane bubbles in the sediment. 16S rRNA and mcrA gene clone libraries were dominated by sequences affiliated to the three known ANME lineages and to putative methanogens. Sequences related to the marine benthic group B (MBG-B) and miscellaneous crenarchaeotal group (MCG) were also detected. However, the highest methane concentration facies was the only section where active Archaea were detected, using reverse-transcribed rRNA, indicating that these communities were involved either directly or indirectly in the methane cycling process. Moreover, three metabolically active novel uncultivated lineages, related to putative methane cycling Archaea, could be specifically associated to these methane bearing sediments. As methane cycling Archaea are commonly retrieved from deep subseafloor and methane seep sediment, the study of coastal gassy sediments, could therefore help to define the biogeochemical habitats of deep biosphere communities.
\end{abstract}

Keywords: Archaea; 16S rRNA; mcrA; methane; sediment 


\section{Introduction}

Over $85 \%$ of the annual emissions of methane are biogenically produced by methanogenesis in various environments (Reeburgh, 2007; Valentine et al., 2004), such as marine sediments which contain the largest global reservoir of methane (Kvenvolden, 1988; Hovland et al., 1993). Deltas and estuaries commonly constitute appropriate settings for methane production due to the rapid accumulation of sediments with high organic matter concentrations (Fleischer et al., 2001). Recent studies on Marennes-Oléron Bay, a macrotidal bay located on the French Atlantic coast, have revealed a kilometer-scale acoustic turbidity (Bertin and Chaumillon, 2005). The acoustic turbidity, interpreted as an accumulation of free gas in the sediment, is correlated with a high sediment gain area in excess of $3 \mathrm{~m}$ since 1824 and could be related to anthropic processes (Bertin and Chaumillon, 2005; Bertin et al., 2005). The lack of thermogenic activity in the bay, and the high primary production could indicate the generation of biogenic methane on decade to century time-scales (Bertin and Chaumillon, 2005). The present study aims at determining whether the acoustic turbidity in an estuarine environment associated with high sedimentation rate is a consequence of methane accumulation and whether active methane cycling microbial communities are involved in this process. Methanogenesis is mediated by methanogenic Archaea and only occurs in anoxic environments 
(Wolfe, 1971). In all known methanogens, the methyl-coenzyme M reductase (MCR) enters the final step in methane synthesis (Ellermann et al., 1988). Therefore, the $m c r A$ gene can be used to target methanogens by using molecular techniques (Springer et al., 1995; Luton et al., 2002). However, over $80 \%$ of the biogenic methane that rises from anoxic marine sediment is consumed by anaerobic methane oxidization (AOM) (Orphan et al., 2001a), therefore representing 5 to $20 \%$ of the net modern atmospheric methane flux (Valentine and Reeburgh, 2000). Molecular techniques have recently shown that AOM is mediated by anaerobic methane oxidizers (ANME) (Boetius et al., 2000, Hinrichs et al., 1999). Three archaeal clades (ANME-1, ANME-2, ANME3) oxidize methane under anaerobic conditions either as single cells or associated to sulfatereducing Bacteria (SRB) (Boetius et al., 2000, Niemann et al., 2006; Orphan et al., 2002). ANME could reverse methanogenesis using a modified MCR (Hallam et al., 2003; Hallam et al., 2004). Although, none of these groups have been obtained in pure culture, a few studies have attempted to investigate the effect of environmental factors on AOM activities of different ANME communities (Nauhaus et al., 2007; Nauhaus et al., 2002b; Valentine and Reeburgh, 2000 ).

It is therefore crucial to target the metabolically active communities in order to correlate their phylogeny with variable environmental factors (Biddle et al., 2006; Sorensen and Teske, 2006. Lloyd et al., 2006; Treude et al., 2005a). However, DNA-based molecular approaches do not distinguish between living and dead microorganisms (Damste and Coolen, 2006, Dell'Anno and Corinaldesi, 2004). Alternatively, fluorescent in situ hybridization has commonly been used to identify metabolically active microorganisms, but this approach does not provide an overall picture of the active microbial communities. In order to target the active cells from subsurface sediments (Inagaki et al., 2005), extractable archaeal rRNA can be used, as rRNA has a rapid turnover rate (Danovaro et al., 1999, Kramer and Singleton, 1993; Kerkhof and Ward, 1993; Kemp et al., 1993). Only a few studies have used rRNA-derived clone libraries to investigate the diversity of active methane cycling communities in subsurface sediments (Biddle et al., 2006; Sorensen and Teske, 2006). Moreover, few studies, to date, have found microbial methane cycling communities in non seep or gas hydrate coastal sediments (Parkes et al., 2007, Treude et al., 2005b; Thomsen et al., 2001). Hence, in this study we conducted an integrated seismic, sedimentologic, biogeochemical and molecular genetic survey of the subsurface gassy sediments of the Marennes-Oléron Bay.

\section{MATERIEL AND METHODS}

\section{Site description and sampling}

The Marennes-Oléron Bay is located on the French Atlantic coast, immediately north of the Gironde Estuary. This bay is a $150 \mathrm{~km}^{2}$ wide semi-enclosed environment connected to the Atlantic Ocean through the Pertuis d'Antioche to the North and to the Maumusson inlet to the South. Intertidal areas represent $60 \%$ of the bay. Two small rivers, the Charente and the 
Seudre, flow into the Marennes-Oléron Bay. Tides affecting the study area are semi-diurnal and range from less than $2 \mathrm{~m}$ to more than $6 \mathrm{~m}$. Swells are strongly attenuated by the narrow entrances of the bay, but wind-waves can produce high turbidity in the water column due to wind-driven resuspension.

The Marennes-Oléron Bay, the first oyster farming area in Europe, is an area of high primary production (466 g. $\mathrm{m}^{-2} \cdot \mathrm{yr}^{-1}$ ) (Bertin and Chaumillon, 2005). Most of the suspended sediments supplied to the bay are derived from the Gironde Estuary (Froidefond et al., 1998). The sediment budget, computed by subtracting the 1824 profile from the 2004 bathymetric digital elevation model, shows a volume difference of $+120.10^{6} \mathrm{~m}^{3}$ for the last 181 years (Bertin and Chaumillon, 2006). This positive sediment budget shows high sedimentation rates, in agreement with $210 \mathrm{~Pb}$ measurement results made on the eastern mudflat of the bay (Gouleau et al., 2000). Very high resolution seismic profiles were recorded in the central Marennes-Oléron Bay during the MOBIDYC5 cruise (2006, CNRS-INSU on board the RV Côte de la Manche). Two cores, M5VC42 and M5VC43 (45 $\left.57^{\prime} \mathrm{N}, 01^{\circ} 10^{\prime} \mathrm{W}\right)$ were collected on the seismic profile m4b31 within the acoustic turbidity area (Figure 2.3a). M5VC42 was used for sedimentary analysis and M5VC43 for biogeochemical and molecular genetic approaches.

\section{Sedimentary analysis}

The $4 \mathrm{~m}$ long M5VC42 core was cut into $1.5 \mathrm{~m}$ slabs that were opened transversely, directly photographed, and described according to the Munsell colour chart. Slabs were X-radiographed using the Scopix system (Migeon et al., 1999). Subsamples for grain-size analyses were performed only where X-ray images showed noticeable changes. Grain-size analyses were carried out using a Malvern Mastersizer diffractometer. Correlation between sedimentologic and seismic data was done on the basis of a depth-to-time conversion of the core datasets, according to the relationships between P-wave velocities and sediment grain size (Hamilton, 1972).

\section{Geochemical analysis}

Methane analyses were performed on core M5VC43 at 30, 60, 90, 120, 150, 180, 210, 240 and 300 centimeters below the seafloor (cmbsf) using the headspace technique (Kolb, 1999). The cores were immediately sub-sampled on board using $5 \mathrm{~mL}$ syringes (luer end removed) and added to headspace vials $(20 \mathrm{~mL})$ filled with a $\mathrm{NaCl} / \mathrm{HgCl}_{2}$ work solution. Methane concentrations were determined using a HP 7694 automatic headspace sampler connected to a HP 5890 gas chromatograph equipped with FID and TCD detectors. The 2-sigma uncertainty was better than $4 \%$. However, methane concentration measurements have to be considered as minimum values as gas escapes occur during core handling. Results were expressed as microlitre per litre wet sediment ( $\mu \mathrm{L} / \mathrm{L}$ wet sediment).

Carbon isotope ratio analyses were carried out on sediment samples collected at different levels: 30, 60, 90, 120, 150, 180, 210, 240 and 300 cmbsf in M5VC42. Inorganic carbon was removed 


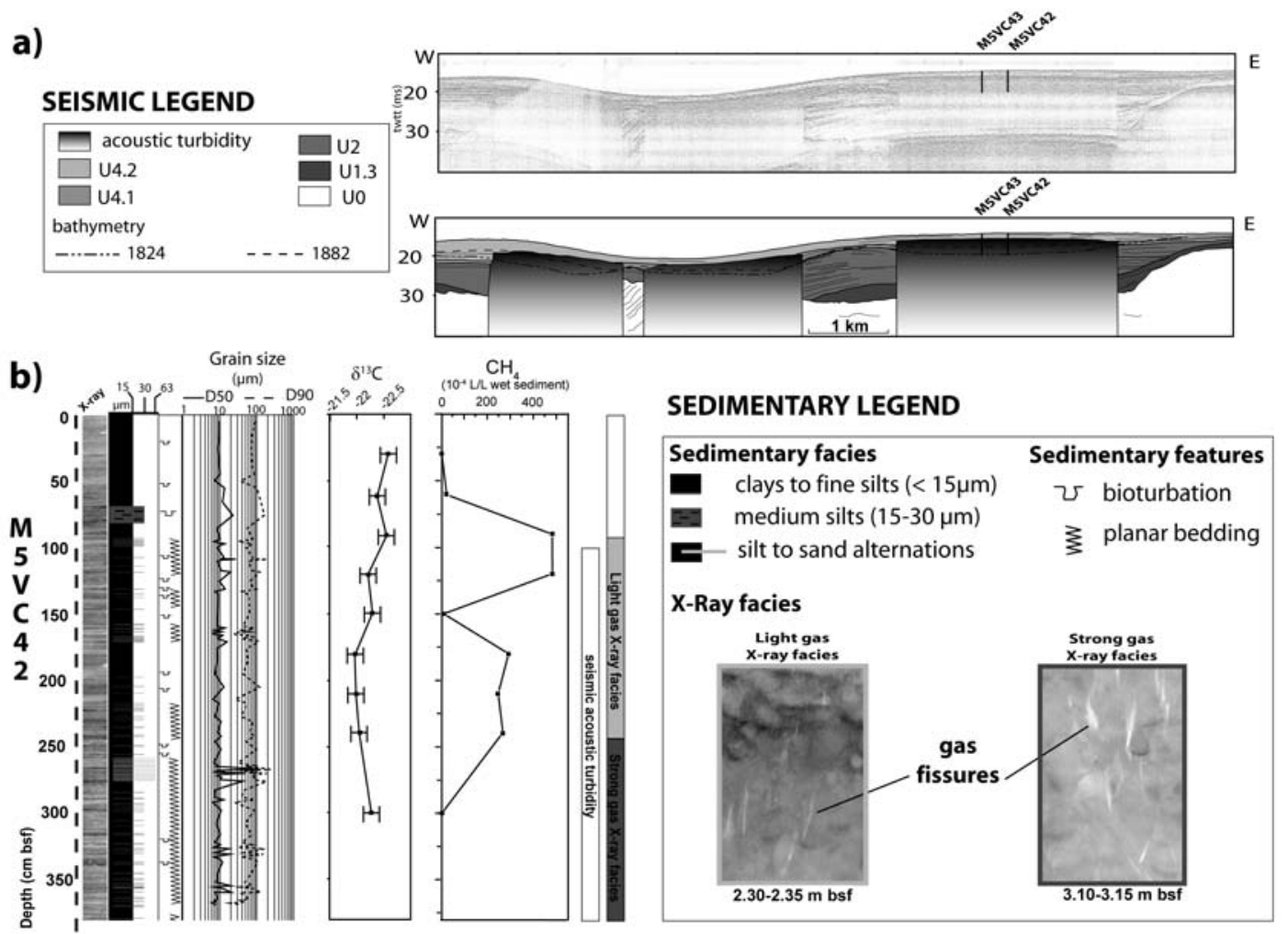

FIG. 2.3: (a) VHR seismic profile m4b31 and its interpretation showing the geometry of the sediment infilling of the northern Marennes-Oléron Bay. Locations of the cores VC42 and VC43 are indicated. Seismic unit U0 corresponds to the bedrock, and seismic units U1.3, U2, U4.1 and U4.2 correspond to the soft sediment incised valley-fill. Locations of the acoustic turbidity areas are indicated. (b) Detailed description of the core VC42. From left to right: elevation in meters (NGF), X-ray image, sedimentary facies, sedimentary features, median grain-size in micrometers, variations in $\delta^{13} \mathrm{C}$ and methane $\left(\mathrm{CH}_{4}\right)$ concentration. Correlation with acoustic turbidity and X-ray facies are also indicated.

by acidification ( $\mathrm{HCl} 2 \mathrm{M} ; 1 \mathrm{~mL} / 100 \mathrm{mg} \mathrm{DW}$ ). To evaporate excess acid, samples were dried overnight at $60^{\circ} \mathrm{C}$ under a hood. They were then mixed to $1 \mathrm{~mL}$ MilliQ water, freeze-dried and finely grounded using a ball mill. Analyses were performed by CF-IRMS using an Isoprime mass spectrometer (Micromass, UK). Results were reported in the standard $\delta^{13} \mathrm{C}$ notation relative to the Vienna PeeDee Belemnite standard (VPDB) where $\delta^{13} \mathrm{C}=\left[\left(\mathrm{R}_{\text {sample }} / \mathrm{R}_{P D B}\right)-1\right] \times 10^{3}$, with $\mathrm{R}={ }^{13} \mathrm{C} /{ }^{12} \mathrm{C}$. Sample analytical precision was $\pm 0.1 \%$.

\section{DNA extractions and PCR amplification}

DNA was extracted from $5 \times 1 \mathrm{~g}$ of uncontaminated frozen sample, core M5VC43 at 0, 60, 90, 125, 185 and 305 cmbsf, following a modified FastDNA ${ }_{\circledast}$ Spin Kit for Soil (Bio101 Systems, MP Biomedicals ${ }^{\mathrm{TM}}$ ) protocol (Webster et al., 2003). Replicate extractions were pooled, purified 
and concentrated in an YM-100 Microcon (Amicon/Millipore ${ }^{\mathrm{TM}}$ ) centrifugal device to give a final volume of $100 \mu \mathrm{L}$.

For the amplification, all manipulations were carried out in a PCR cabinet, using Rnase/Dnase Free Water (MP Biomedicals ${ }^{\mathrm{TM}}$ ) and performed using a GeneAmp PCR system 9700® (Applied Biosystems $\left.^{T M}\right)$. All PCR mixtures $(50 \mu \mathrm{L})$ contained $5 \mu \mathrm{L}$ of DNA template, $1 X$ Taq DNA polymerase buffer (MP Biomedicals ${ }^{\mathrm{TM}}$ ), $1 \mu \mathrm{L}$ of dNTP $(10 \mathrm{mM}$ of each dATP, dCTP, dGTP and dTTP), $10 \mu \mathrm{M}$ of each primer and $0.5 \mu \mathrm{L}$ of Taq DNA polymerase (MP Biomedicals ${ }^{\mathrm{TM}}$ ). Negative controls were also carried out with DNA extractions performed with no sample. For all negative controls, no PCR products were observed. Inhibition of PCR amplification by soluble contaminants in the DNA extracts was also tested as described elsewhere (Juniper et al., 2001). For all DNA extracts, no PCR inhibition was observed.

Archaeal 16S rRNA gene amplification was conducted by nested PCR with combination of primers A8f (5'-CGG TTG ATC CTG CCG GA-3') and A1492r (5'-GGC TAC CTT GTT ACG ACT T-3') in the first round (Casamayor et al., 2000), with A344f (5'-AYG GGG YGC ASC AGG SG-3') and A915r (5'-GTG CTC CCC CGC CAA TTC CT-3') in the second round (DeLong, 1992; Eden et al., 1991). PCR cycles for the first round (A8f/A1492r) were as follows: 1 cycle of 5 min at $94^{\circ} \mathrm{C}, 30$ cycles of $1 \mathrm{~min}$ at $94^{\circ} \mathrm{C}, 1.5 \mathrm{~min}$ at $51^{\circ} \mathrm{C}$ and $2 \mathrm{~min}$ at $72^{\circ} \mathrm{C}$ and 1 cycle of 6 min at $72^{\circ} \mathrm{C}$. PCR cycles for the second round (A344f/A915r) were: 1 cycle of 3 min at $94^{\circ} \mathrm{C}, 30$ cycles of $1 \mathrm{~min}$ at $94^{\circ} \mathrm{C}, 1.5 \mathrm{~min}$ at $57^{\circ} \mathrm{C}$ and $2 \mathrm{~min}$ at $72^{\circ} \mathrm{C}$, and 1 cycle of 5 min at $72^{\circ} \mathrm{C}$. Five independent PCR products from the first round were pooled and purified (QIAquick PCR purification Kit; Qiagen ${ }^{T M}$ ) and used as template for the second round. This nested PCR was necessary to obtain visible PCR products on a $0.8 \%(\mathrm{w} / \mathrm{v})$ agarose gel stained with ethidium bromide. A portion of the $m c r A$ gene was amplified using the ME primers (Hales et al., 1996). To obtain visible amplification products, two rounds with the following reaction conditions were performed: 1 cycle of $5 \mathrm{~min}$ at $94^{\circ} \mathrm{C}, 30$ cycles of $45 \mathrm{~s}$ at $94^{\circ} \mathrm{C}, 1.5 \mathrm{~min}$ at $50^{\circ} \mathrm{C}$ and $2 \mathrm{~min}$ at $72^{\circ} \mathrm{C}$, and 1 cycle of $10 \mathrm{~min}$ at $72^{\circ} \mathrm{C}$. An aliquot $(5 \mu \mathrm{L})$ of 3 pooled PCR products of the primary amplification was used as templates for the second amplification round.

\section{RNA extractions and RT-PCR amplification}

Total RNA was extracted from each uncontaminated frozen sample $(5 \times 1 \mathrm{~g})$ of the M5VC43 core $(0,60,90,125,185$ and $305 \mathrm{cmbsf})$ using the FastRNA ${ }_{\circledast}$ Pro soil direct Kit (Bio101 Systems, MP Biomedicals ${ }^{\mathrm{TM}}$ ) following the manufacturer's instructions. To digest trace amounts of DNA, the extraction products were pooled and $150 \mu \mathrm{L}$ were incubated 1 hour at $37^{\circ} \mathrm{C}$ with $1 \mathrm{X}$ of TURBO DNase ${ }^{\circledR}$ buffer and $18 \mathrm{U}$ of TURBO DNase ${ }^{\circledR}\left(\right.$ Ambion $\left.^{\mathrm{TM}}\right)$. The digestion was stopped by adding EDTA to a final concentration of $15 \mathrm{mM}$ and heating $10 \mathrm{~min}$ at $65^{\circ} \mathrm{C}$. The product was finally concentrated and purified with the RNeasy minikit (Qiagen ${ }^{\mathrm{TM}}$ ) according to the manufacturer's instructions to give a final volume of $100 \mu \mathrm{L}$.

The purified RNA product was immediately serially diluted (1 to 50 times) and reverse transcribed using the OneStep RT-PCR kit (Qiagen ${ }^{T M}$ ), according to the manufacturer's instructions, 
with combination of $16 \mathrm{~S}$ rRNA primers for Archaea with A8f (5'-CGG TTG ATC CTG CCG GA-3') and A1492r (5'-GGC TAC CTT GTT ACG ACT T-3') and the following touchdown PCR protocol: $30 \mathrm{~min}$ at $50^{\circ} \mathrm{C}, 15 \mathrm{~min}$ at $95^{\circ} \mathrm{C}$ followed by 20 cycles of $1 \mathrm{~min}$ at $94^{\circ} \mathrm{C}, 1 \mathrm{~min}$ at $58^{\circ} \mathrm{C}$ (decreasing $0.5^{\circ} \mathrm{C}$ every cycle), 4 min at $72^{\circ} \mathrm{C}$, then followed by 20 cycles of $1 \mathrm{~min}$ at $94^{\circ} \mathrm{C}, 1 \mathrm{~min}$ at $51^{\circ} \mathrm{C}, 4 \mathrm{~min}$ at $72^{\circ} \mathrm{C}$ and a final amplification step of $10 \mathrm{~min}$ at $72^{\circ} \mathrm{C}$. To obtain visible products, a nested PCR was performed as described for the 16S rRNA gene amplification. Nested PCR assays, using the 16S rRNA primers for Archaea, without the reverse transcription step, showed no DNA contamination.

\section{PCR-DGGE analysis}

In order to characterize the general archaeal community depth structure, a 16S rRNA gene PCR-DGGE analysis was undertaken. Nested PCR was performed as described for the archaeal 16S rRNA gene amplification using primers Saf and PARCH 519R as previously described (Nicol et al., 2003). PCR products were analyzed by DGGE using a DCode Universal Mutation Detection System ${ }_{\circledast}\left(\right.$ BioRad $\left.^{\mathrm{TM}}\right)$ on a $1 \mathrm{~mm}$ thick $(16 \times 16 \mathrm{~cm}) 8 \%(\mathrm{w} / \mathrm{v})$ polyacrylamide gel (acrylamide/bisacrylamide, $40 \%, 37,5: 1, \operatorname{BioRad}^{\mathrm{TM}}$ ). The gel had a denaturant gradient between 30 and $60 \%$ and was prepared with 1X TAE buffer (pH 8, 40 mM Tris Base, $20 \mathrm{mM}$ acetic acid, $1 \mathrm{mM}$ EDTA, MP Biomedicals ${ }^{\mathrm{TM}}$ ) and poured "Gradient maker" (Hoefer $\mathrm{SG} 30_{\circledast}$ ). Electrophoresis was carried in $1 \mathrm{X}$ TAE buffer at $60^{\circ} \mathrm{C}$ for $330 \mathrm{~min}$ at $200 \mathrm{~V}$ (initially at $80 \mathrm{~V}$ for $10 \mathrm{~min}$ ). The gel was stained with SYBRGold ${ }_{\circledR}$ nucleic acid gel stain for $45 \mathrm{~min}$, washed for 10 min with $1 \mathrm{X}$ TAE buffer and scanned using a Phospho fluorimager Typhoon 9400® $\left(\right.$ Amersham Biosciences $\left.{ }^{T M}\right)$.

\section{Cloning and sequencing}

According to archaeal DGGE profiles, clone libraries were constructed: a) three DNA-derived 16SrRNA gene (DNA65, DNA125 and DNA185), b) two RNA-derived 16S rRNA gene (RNA95 and RNA125), and c) six DNA-derived mcrA gene (mcr0, mcr60, mcr90, mcr125, mcr185 and mcr305). The number indicates the depth of each sample (cmbsf). To minimize PCR bias (Polz and Cavanaugh, 1998), five independent PCR products were pooled and purified (QIAquick PCR purification Kit; Qiagen ${ }^{\top M}$ ) and cloned into Escherichia coli (XL10-Gold® ${ }_{\circledast}$; Stratagene ${ }^{\top M}$ ) using the pGEM-T Easy vector system I (Promega ${ }^{\text {TM }}$ ) following the manufacturer's instructions. Positive transformants were screened by PCR amplification of the insert using the vector-specific M13 primers. Plasmid extraction, purification and sequencing of the insert, were carried out by the sequencing OUEST-Genopole platform ${ }_{\circledR}$ of Roscoff Marine laboratory (France).

\section{Phylogenetic analysis}

All the $16 \mathrm{~S}$ rRNA base pair sequences ( $\sim 553$ bases) were checked for chimeras, using the CHIMERA-CHECK version 2.7 algorithm from the RDP-II (Cole et al., 2003). Out of a 
total of 376 sequences (including those from the 16S rRNA gene and mcrA gene), 2 were found to be chimeras and were excluded from the phylogenetic analyses. The phylogenetic placement was carried out using NCBI BLAST search program within GenBank (http:// www.ncbi.nlm.nih.gov/blast) (Altschul et al., 1990). The 16S rRNA sequences were then edited in the BioEdit 7.0.5.3 program (Hall, 1999) and aligned using CLUSTALW (Thompson et al., 1994). The phylogenetic trees were constructed by the PHYLO-WIN program (http: //pbil.univ-lyon1.fr/) (Galtier et al., 1996) with neighbour-joining method (Saitou and Nei, 1987) and Jukes and Cantor correction. The nonchimeric mcrA sequences ( $\sim 770$ bases) were translated into amino acids using BioEdit and then aligned using CLUSTALW. The PHYLOWIN program with neighbor-joining algorithm and PAM distance (Dayhoff et al., 1978) was then used for phylogenetic tree construction. For the $16 \mathrm{~S}$ rRNA and $m c r A$ gene phylogenetic reconstruction, the robustness of inferred topology was tested by bootstrap resampling (500), values over $50 \%$ are shown on the trees. The richness from the clone libraries was estimated, with the rarefaction curves at $99 \%, 97 \%$ and $95 \%$ sequence identity levels, using the DOTUR program (Schloss and Handelsman, 2005). Operational taxonomic units (OTUs), using a $97 \%$ sequence similarity, were generated with the SON program (Schloss and Handelsman, 2006) and the percentage of coverage $(\mathrm{Cx})$ of the clone libraries was calculated by Good's method (Good, 1953) as described by Singleton and colleagues (Singleton et al., 2001). Statistical estimators, the significance of population differentiation among clone libraries $\left(\mathrm{F}_{S T}\right)$ Martin, 2002), and the exact tests of population genetic differentiation (Raymond and Rousset, 1995), were calculated using Arlequin 3.11 (Excoffier et al., 2005).

\section{Nucleotide sequence accession numbers}

The sequences are available from GenBank database under the following accession numbers: $16 \mathrm{~S}$ rRNA gene and rRNA (AM942119 to AM942178) and mcrA gene (AM942079 to AM942118).

\section{RESUlTS AND DISCUSSION}

\section{High methane concentration in the gassy sediments}

$\mathrm{X}$-ray images revealed that physical structures were dominated by millimeter to centimeterthick planar bedding corresponding to strong and low X-ray attenuations. X-ray also showed that sediment was slightly bioturbated (Figure 2.3p). Three major X-ray facies were identified. From the top of the core to $95 \mathrm{cmbsf}, \mathrm{F} 1 \mathrm{X}$-ray facies consisted of poorly laminated sediments. From 95 to 245 cmbsf, F2 X-ray facies consisted of laminated sediments showing sparse subvertical and elongated fissures (about $1 \mathrm{~cm}$ long and less than $1 \mathrm{~mm}$ wide). The transition from F1 to F2 X-ray facies was close to the acoustic turbidity upper boundary observed on m4b31 seismic profile at about $100 \mathrm{cmbsf}$ (Figure 2.3). From 245 to $380 \mathrm{cmbsf}$, F3 X-ray facies consisted of laminated sediments showing several sub-vertical and elongated fissures (about 1 
$\mathrm{cm}$ long and more than $1 \mathrm{~mm}$ wide). No such fissures were observed in cores collected outside acoustic turbidity areas (Billeaud et al., 2005). Grain size analyses showed that sediments were mainly composed of black clay to fine silts $(<15 \mu \mathrm{m})$ alternating with dark greenish $(5 \mathrm{Y} 4 / 1)$ coarse silt (30 to $63 \mu \mathrm{m})$ and sparse very fine sand (63 to $125 \mu \mathrm{m}$ ) layers. These grain-size alternation layers were often correlated with X-ray attenuation. However the transitions between F1-F2 and F2-F3 X-ray facies did not match with any grain size change.

The acoustic turbidity layer (Figure 2.3 ), evidenced by seismic profiles, was correlated with the highest sedimentation rates of the bay (Bertin and Chaumillon, 2005). Moreover, the acoustic turbidity upper boundary matched with the top of F2 X-ray facies displaying fissures and with the highest methane concentrations (Figure 2.3 and 2.4). In contrast, other studies have found the acoustic turbidity upper boundary below the methane peak concentration Abegg and Anderson, 1997, Thiessen et al., 2006). Hence, both acoustic turbidity and elongated fissures demonstrated the existence of methane bubbles in the sediment (Abegg and Anderson, 1997). The occurrence of gas bubbles suggests that the sediment pore-fluids were saturated with methane. In oversaturated cores, it is well-known that most (up to $95 \%$ ) of the methane escapes during core recovery due to the significant decrease of methane solubility related to pressure and degassing (Hensen et al., 2007). This gas loss during ex situ sampling could explain the variation in methane concentration below $120 \mathrm{cmbsf}$ because the bubble repartition and the degassing were probably not homogeneous in the sediment core.

However, the general methane concentration profile in sediment pore-fluids (Figure 2.4b) was similar to the ones found in coastal marine sediments or tidal flats (Parkes et al., 2007; Wilms et al., 2007; Thomsen et al., 2001). At $30 \mathrm{cmbsf}$, the $\mathrm{CH}_{4}$ concentration was relatively low ( $\sim 4 \mu \mathrm{L} / \mathrm{L}$ wet sediment), probably reflecting the regional background. At $60 \mathrm{cmbsf}$ the $\mathrm{CH}_{4}$ concentration increased with depth, reaching a maximum peak value of $483 \mu \mathrm{L} / \mathrm{L}$ wet sediment between 90 and $120 \mathrm{cmbsf}$, which matched the acoustic turbidity upper boundary, and which generally corresponds to the sulfate methane transition zone (SMTZ) (Iversen and Jorgensen, 1985, Thomsen et al., 2001). However, this hypothesis would need to be confirmed by sulfate analyses.

Values of $\delta^{13} \mathrm{C}(-22.0$ and $-22.6 \%$ ) were intermediate between values in shallower depths (15$30 \mathrm{cmbsf}$ ) of the intertidal mudflats lining the bay (Figure 2.3p): $-20.2 \%$ on the western side (Oléron Island), -23.0\%oon the continental side. Inputs from the continental side thus seem to have more influence on the organic matter origin in the studied cores, assuming negligible changes occurred during diagenesis (Sackett, 1964). On the continental side of the bay, organic matter was mainly of microalgal origin in the surficial layers and consisted of a mixture of sedimented estuarine phytoplankton $(-22.7 \%$ ), of a larger fraction of microphytobenthos ($16 \%$ ), and of ${ }^{13} \mathrm{C}$-depleted terrestrial material (-28\%0) (Riera and Richard, 1996), while in deeper layers this later became more abundant. A slight and irregular decrease in the organic carbon content was observed with increasing depth. In average $0.83 \% \mathrm{C}$ was measured 


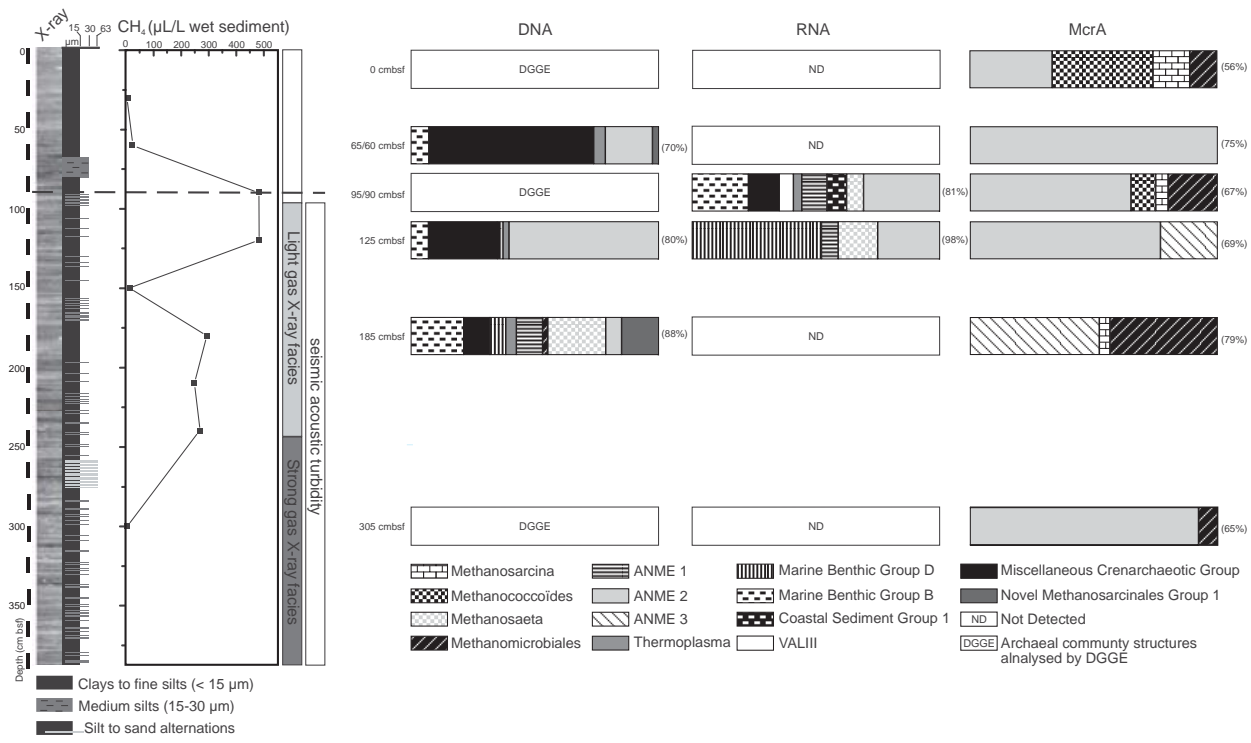

FIG. 2.4: Depth distribution of the archaeal phylogenetic community structures based on $16 \mathrm{~S}$ rRNA, crRNA and mcrA gene compared to X-ray image, sedimentary facies and methane $\left(\mathrm{CH}_{4}\right)$ concentration. The percentage of coverage of each clone library examined is indicated in brackets. The phylogenetic affiliation of each clone sequence was determined by similarity analysis. The relative abundance of each phylotypes in the clone library was calculated and represented in a column diagram. DNA designs the DNA-derived libraries; RNA, the RNAlibraries; McrA, the $m c r A$ gene libraries.

(dry sediment collected in M5VC42 core) which was about twice the $0.46 \% \mathrm{C}$ detected in a core collected outside the acoustic turbidity. These relatively large amounts of organic matter combined with the highest sedimentation rates of the bay (Bertin and Chaumillon, 2005) could create ideal settings for active methanogenic microbial communities producing high amounts of biogenic methane (Valentine, 2002).

\section{Archaeal diversity depth distribution}

Analysis of the clone libraries. Eleven different clone libraries were constructed, representing a total of 376 sequences. All the DNA-derived 16S rRNA PCR products from all depths were screened by DGGE prior cloning, in order to select the most representative phylogenetic diversities of the core (Webster et al., 2003). Hence, three depths were chosen to construct DNA-derived clone libraries. The whole $16 \mathrm{~S}$ rRNA sequences, derived from RNA and DNA, were assigned to 48 OTUs based on a $95 \%$ genus level of phylotype differentiation (Schloss and Handelsman, 2004). After technical optimisation, archaeal amplifiable DNA was only retrieved by nested PCR from all depths and 17, 11 and 14 OTUs were respectively assigned to DNA65, DNA125 and DNA185 clone libraries. Amplifiable RNA was detected only from $95 \mathrm{cmbsf}$ and 125 cmbsf depths, which are correlated with the highest methane concentrations. The 
two RNA-derived clone libraries from these depths were respectively assigned with 27 OTUs and 5 OTUs. The coverage values for the $16 \mathrm{~S}$ rRNA clone libraries ranged from 70 to $98 \%$ (Figure 2.4). Rarefaction curves were strongly curvilinear for all the libraries attesting for a sufficient sampling effort (data not shown).

The molecular techniques (PCR and cloning), used to build clone libraries, are known to be inherently biased (Suzuki and Giovannoni, 1996; Polz and Cavanaugh, 1998). However, the ratios between the $16 \mathrm{~S}$ rRNA gene and rRNA per cell have been reported to be proportional to the metabolic activity of the cells, the rRNA content per cell increasing with metabolic activity (Danovaro et al., 1999; Kramer and Singleton, 1993; Kerkhof and Ward, 1993; Kemp et al., 1993). As ANME-1 and Methanosaeta lineages were detected in RNA125 library, but absent in DNA125 library, we hypothesized that the sediments at $125 \mathrm{cmbsf}$ could harbor low cell concentrations of very active ANME-1 and Methanosaeta lineages. Moreover, insignificant $\mathrm{F}_{S T}$ and $\mathrm{P}$ tests $(\mathrm{P}<0.01)$ suggested that the sequences from the DNA185 library, compared to the RNA95 and RNA125 libraries, were from similar lineage distributions and were indistinguishable from the combined communities (Martin, 2002). DNA derived libraries in marine sediments, built from short $16 \mathrm{~S}$ rRNA fragments, could result partially from the DNA amplification of dead, quiescent cells (Dell'Anno and Danovaro, 2005; Corinaldesi et al., 2005). For this reason, we suggest that the DNA derived from the different lineages detected at depth was also the result of the accumulation, during the sedimentation process, of the undegraded DNA from dead, quiescent and active communities from the shallower depths. Hence, the ANME-1 and Methanosaeata lineages detected in the DNA185 library could be the consequence of an accumulation of DNA from dead or quiescent cells from the shallowest depths (95-125 cmbsf) where they were found active.

The 16S rRNA clone libraries were, on the whole, dominated by sequences related to Euryarchaeota (65\%), except for DNA65 where Crenarchaeota were a majority (74 \%; Figure 2.4. The archaeal phylogenetic diversity was quite high, forming a total of 11 different lineages: ANME-1, ANME-2, Methanosaeta, Methanomicrobiales, Thermoplasmales, Marine Benthic Group D (MBG-D), Miscellaneous Crenarchaeotal Group (MCG), Marine Benthic Group B (MBG-B), and 3 novel lineages (Figure 2.5 and 2.6). Unexpectedly, no sequences related to the Marine Group 1 (MG-1) Archaea, an ubiquitous Archaea in marine sea beds were detected. Furthermore, the general phylogenetic diversity of the shallow gassy sediments of MarennesOléron Bay was similar to the one retrieved from methane bearing environments such as cold seeps and gas hydrates (Kendall et al., 2007; Knittel et al., 2005), mainly characterized by a large proportion of methanogens and methane oxidizers. A majority of sequences were related to uncultured environmental clones from these environments (highest similarity to pure culture, $98 \%)$.

Archaeal methane oxidizing communities. ANME Archaea mediate AOM (Boetius et al., 2000 Hinrichs et al., 1999), and dominated the 16S rRNA (34 \%) and the mcrA libraries (74 \%) 


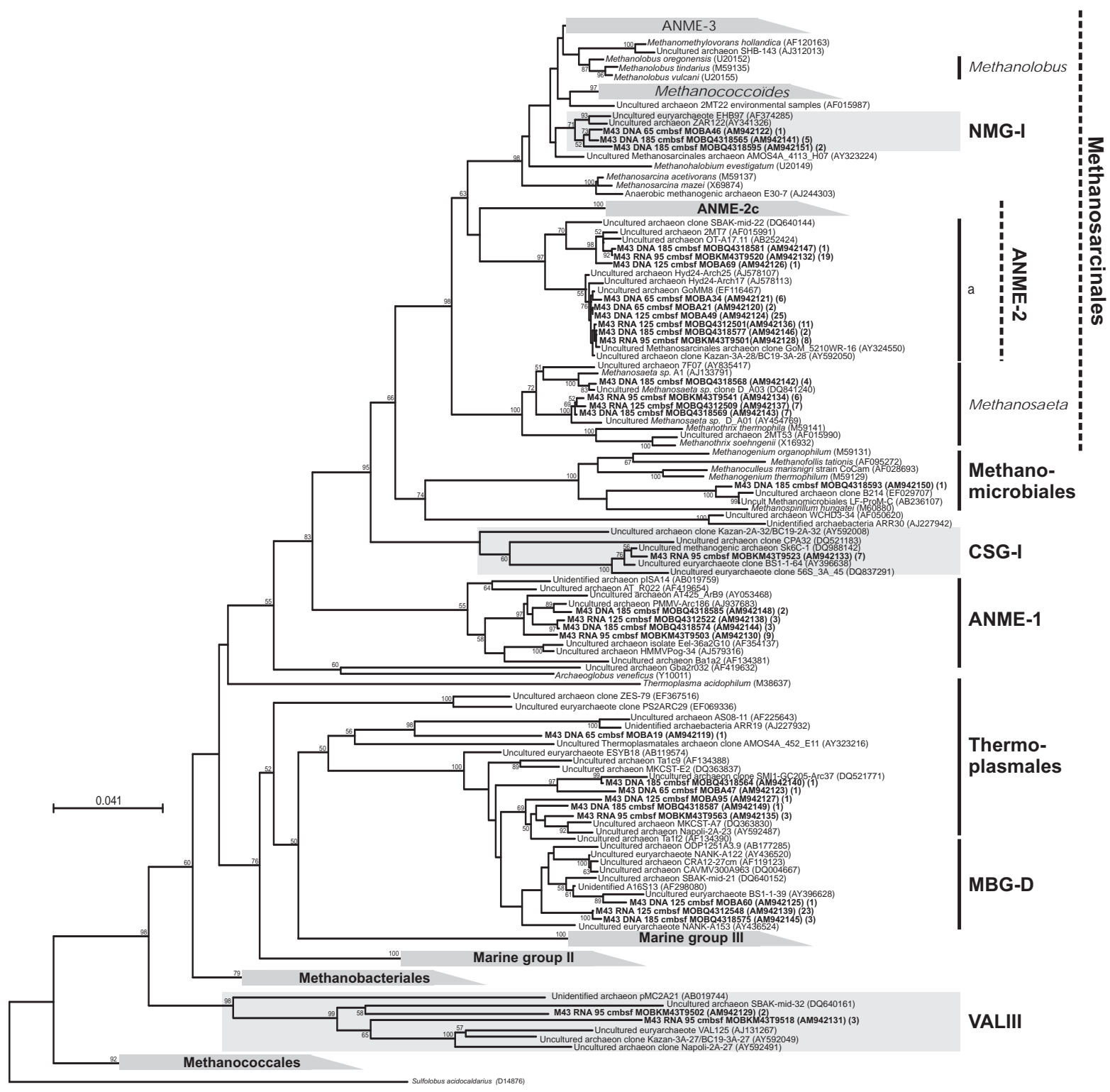

FIG. 2.5: Phylogenetic tree representing the Euryarchaeota 16S rRNA gene sequences DNAand RNA derived, designed by DNA and RNA respectively. Each phylotype is represented by one sequence with $>97 \%$ similarity grouping. The tree was constructed using the neighbour-joining method with Jukes and Cantor correction. Bootstrap values $<50 \%$ are not shown. CSG-1: Coastal Sediment Group 1, MBG-D: Marine Benthic Group D, NMG-1: Novel Methanosarcinales group 1, VALIII: VAL III cluster (Jurgens et al., 2000). 


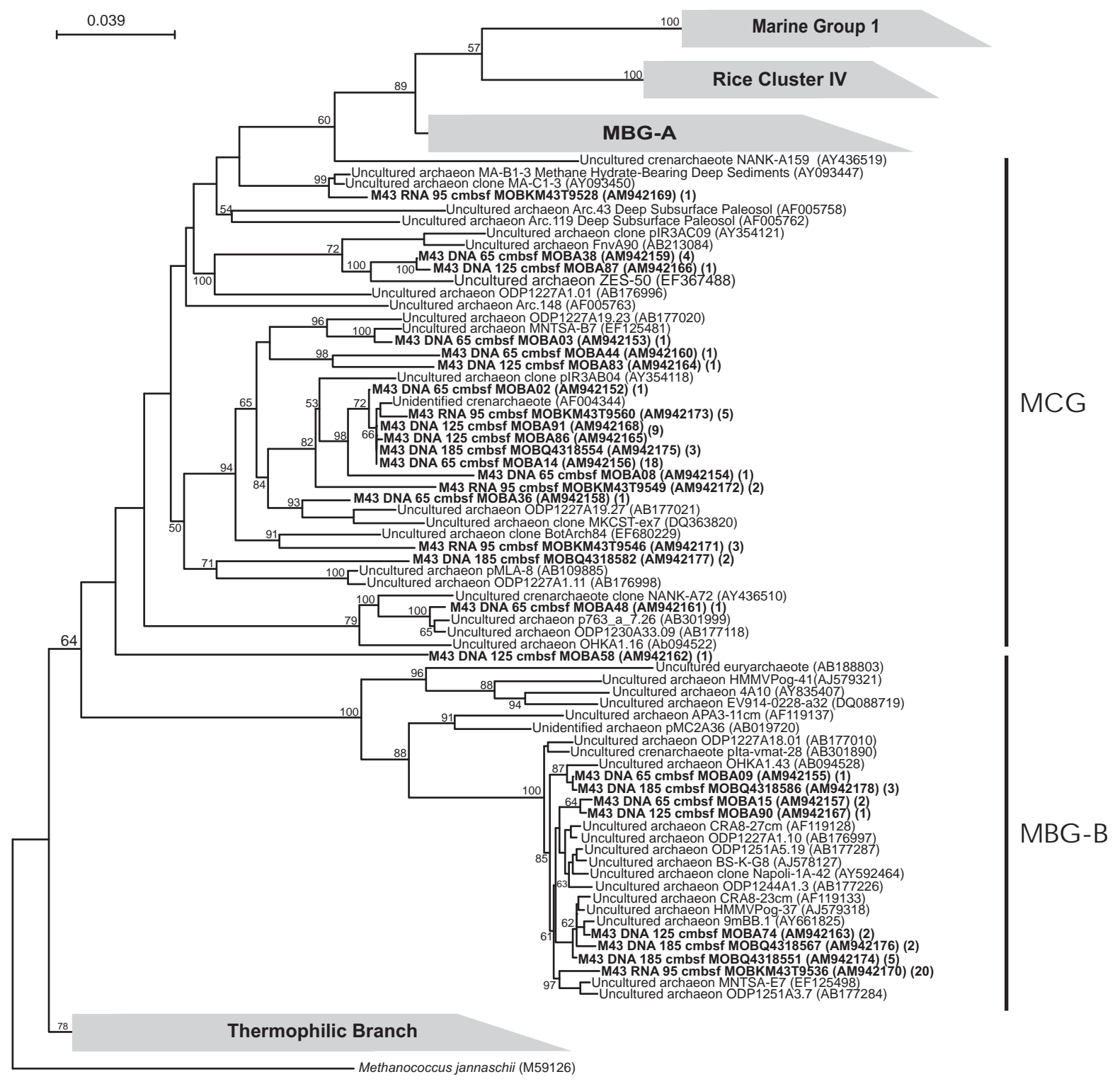

FIG. 2.6: Phylogenetic tree representing the Crenarchaeota 16S rRNA gene sequences DNAand RNA derived, designed by DNA and RNA respectively. Each phylotype is represented by one sequence with $>97 \%$ similarity grouping. The tree was constructed using the neighbourjoining method with Jukes and Cantor correction. Bootstrap values $<50 \%$ are not shown. MCG: Miscellaneous Crenarchaeotal Group, MBG-B: marine benthic group B, MBG-A: Marine Benthic Group A. 
(Figure 2.4. Sequences related to ANME-2a, representing $28 \%$ of the clones in the libraries, were most abundant in the DNA125 (61\%). These sequences were shown to form 2 clusters (Figure 2.5); the first cluster is affiliated to sequences from cold seep environments (Heijs et al., 2007). The second cluster is related to sequences from salt marshes (unpublished) and $\mathrm{CO}_{2}$ hydrate-bearing sediments (Inagaki et al., 2006a). Moreover, the 6 mcrA libraries ( $\mathrm{n}=112$, coverage $=69 \%$ ) were also dominated by sequences related to ANME-2a (61\%), except at 185 cmbsf where they were replaced by ANME-3 (52\%) (Figure 2.4). The sequences related to ANME-2 formed also two clusters within the McrA group e (Figure 2.7). However, ANME-2a sequences from DNA-derived libraries were also present at all depths, whereas ANME-1 were detected only in the deeper parts of the core, (below $95 \mathrm{cmbsf}$ ) as previously described in other environments (Knittel et al., 2005; Nunoura et al., 2006). The depth-dependant distribution of ANME-1 tends to support the hypothesis that they are more sensitive to oxygen and to lower temperatures than AMNE 2 (Knittel et al., 2005; Nauhaus et al., 2005). Active ANME-1 were also detected at the highest methane concentrations suggesting that ANME-1 are present at high methane flow rates (Girguis et al., 2005) (Figure 2.4). Moreover, Orcutt and colleagues have recently proposed that ANME-1 could also be involved in methanogenesis depending on the environmental conditions (Orcutt et al., 2005). Although the operon coding for the MCR-I, which includes McrA subunit, is found in all known methanogens (Reeve et al., 1997), ANME-1 and ANME-3 were detected only by one type of primer couple (Figure 2.4), whereas ANME-2a were found among the $m c r A$ and $16 \mathrm{~S}$ rRNA libraries. The absence of $m c r A$ sequences related to ANME-1, detected at the same depth 16S rRNA clone libraries, could be the consequence of the lower percentages of coverage of the mcrA libraries or due to a higher number of copies per genome of 16S rRNA gene than mcrA (Nunoura et al., 2006).

Moreover, RNA-derived libraries (RNA95 and RNA125) were also dominated by sequences related to these ANME lineages (36 \%; Figure 2.4), suggesting that these Archaea were also metabolically active. These Archaea were detected between 95 and $125 \mathrm{cmbsf}$, where the methane concentration was the highest. The archaeal communities associated with the other depths were either below the detection limit or less metabolically active. Therefore, AOM could represent one of the major archaeal microbial activities in these sediments.

Archaeal methanogenic communities. Sequences affiliated to archaeal methanogenic lineages represented an important component of the total libraries $(26 \%)$ and were composed of Methanococcoïdes, Methanosarcina, Methanosaeta and Methanomicrobiales (Figure 2.4). However, putative methanogens represented less than $10 \%$ of the $16 \mathrm{~S}$ rRNA libraries and were found only below the highest methane concentration zone (95 cmbsf). A large proportion of these sequences $(9 \%)$ were related to the Methanosaeta lineage. Only one sequence is related to the Methanomicrobiales lineage. In $m c r A$ libraries, the depth distribution of the methylotrophic Methanococcoïdes and Methanosarcina decreased with depth and seems to be therefore restricted to the shallowest part of the core. The methanogens utilizing $\mathrm{C} 1$ compounds usually 


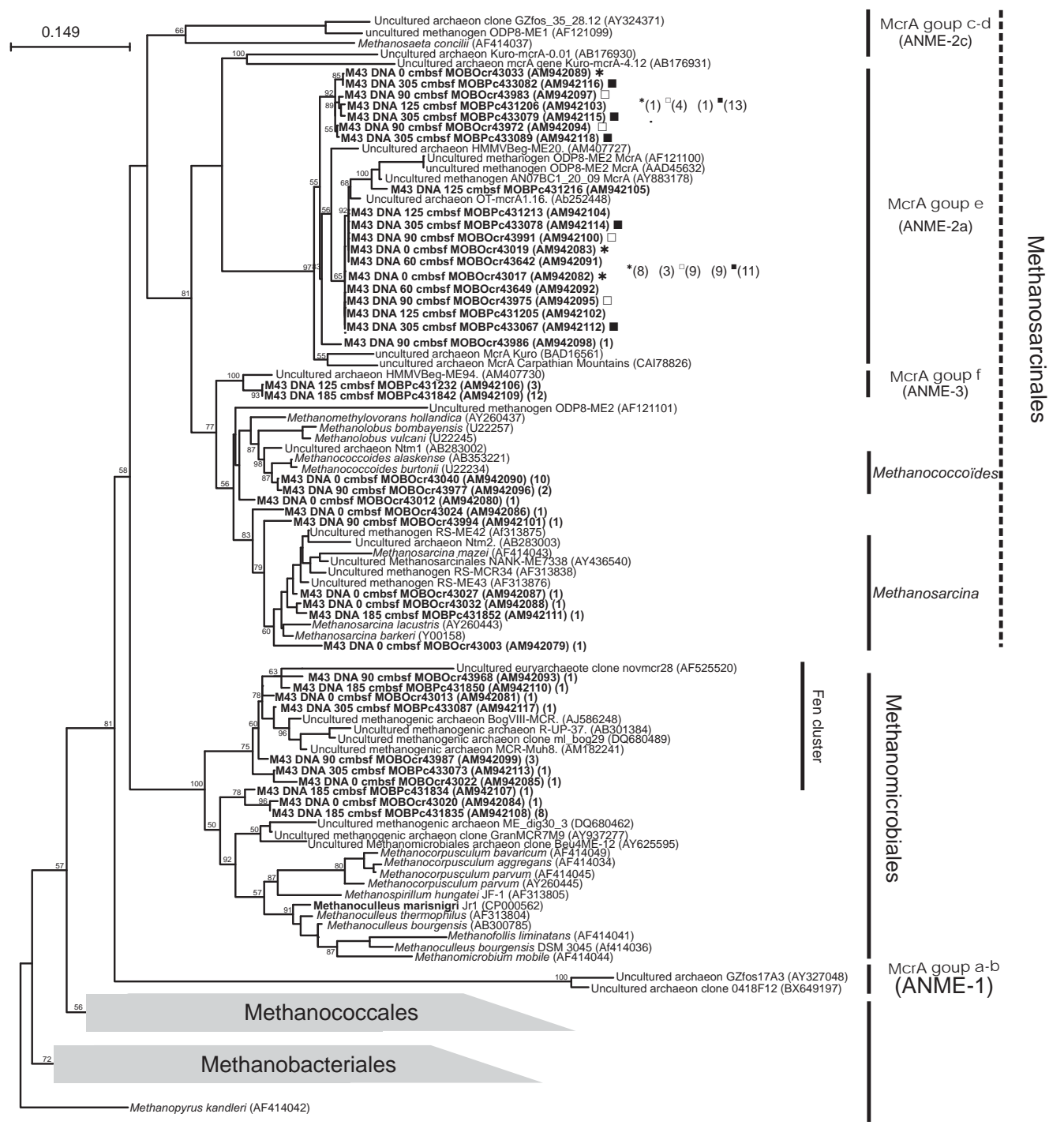

FIG. 2.7: Phylogenetic tree based on translated, partial amino acid sequences of mcrA gene ( $<260$ amino acids). The tree was constructed using the neighbour-joining method using PAM distance (Dayhoff et al., 1978). The robustness of inferred topology was tested by the bootstrap. Bootstrap values $<50 \%$ are not shown. 
dominate the marine methanogens within the zone of sulfate reduction since sulfate reducing Bacteria (SRB) do not compete for the same substrates (Purdy et al., 2003). Conversely sequences related to Methanosaeta, an acetoclastic methanogens (Ma et al., 2006), were detected only below $95 \mathrm{cmsf}$ (Figure 2.4), given that SRBs out-compete acetoclastic methanogens in the zone of sulfate reduction. Nine sequences related to the $\mathrm{H}_{2} / \mathrm{CO}_{2}$-utilizing Methanomicrobiales (Zellner et al., 1999) were detected at all depths even though they were found in higher proportions in the libraries at $185 \mathrm{cmbsf}$ and branched in the Fen cluster (Juottonen et al., 2006), a group of environmental clones from peatlands (Figure 2.4 and 2.7 ).

Subsurface sediment Archaeal communities. The Crenarchaeota sequences were related to the Marine Benthic Group B (MBG-B) and Miscellaneous Crenarchaeotic Group (MCG) lineages (Figure 2.6), representing $35 \%$ of the $16 \mathrm{~S}$ rRNA clone libraries, and were also detected among the core (Figure 2.4). The proportion of MBG-B sequences in the libraries increases with depth (Figure 2.4) and forms two distinct clusters with environmental clones (Figure 2.6) . The MBG-B Archaea, a deep-branching lineage within Crenarchaeota, were found to be most active where the methane concentration was the highest (95 cmbsf). MBG-B, also synonymous of Deep Sea Archaeal Group (DSAG), have been previously detected in a wide range of anoxic marine environments (Takai and Horikoshi, 1999; Lloyd et al., 2006, Biddle et al., 2006; Sorensen and Teske, 2006). Recent studies have also revealed that MBG-B were metabolically active within the SMTZ, suggesting that MBG-B were directly or indirectly linked to AOM (Biddle et al., 2006: Inagaki et al., 2006b; Sorensen and Teske, 2006; Teske and Sorensen, 2008). MCG sequences dominated the shallowest library (DNA65) (67\%) and were also found, in smaller proportions, in all libraries (Figure 2.4) . The MCG, an ubiquitous lineage in marine sediments, were also active at $95 \mathrm{cmbsf}$, and are thought to be heterotrophic anaerobes utilizing complex organic substrates (Teske and Sorensen, 2008).

Sequences related to uncultured Thermoplasmales and MBG-D lineages were also found in small proportions in the DNA-retrieved libraries $(7 \%)$, at all depths. However, sequences related to MBG-D dominated (52\%) the RNA-derived library below 95 cmsf. This lineage within the Thermoplasmatales is also frequently found in methane seep sediments (Knittel et al., 2005; Orphan et al., 2001a) and deep marine sediments (Parkes et al., 2005; Sorensen and Teske, 2006).

Novel archaeal lineages. In the present study, three potential new lineages with no closely related culture isolates were detected in high methane concentration zones. The first novel lineage, formed an independent cluster within the methane cycling Methanosarcinaceae family. This group of 8 sequences were closely related to environmental clones from low salinity methane-harboring environment such as a sulfide rich spring (Elshahed et al., 2004) and estuary sediments (Purdy et al., 2002). This new potential cluster, distantly related to the methylotrophic Methanolobus oregonensis (96 \% similarity), was named Novel Methanosarci- 
nales group 1 (NMG-1).

The detection by RNA-based approaches of active novel lineages in methane-bearing environments led to the discovery of the ANME lineages (Niemann et al., 2006; Hinrichs et al., 1999 Orphan et al., 2001b). Interestingly, the RNA-derived sequences usually fell with the same phylotypes as the DNA-derived sequences, except for 2 groups of sequences that formed novel lineages (Figure 2.5). These two novel lineages were found metabolically active with a majority of the methane cycling communities (AMNE, MBG-B and Methanosaeta), where the sediments harbored the highest methane concentrations. Moreover the second novel lineage, designed as the Coastal Sediment group-1 (CSG-1), deeply branching within Euryarchaeota phylum, was distantly related to the Mehanosarcinales family (Figure 2.5). The CSG-1 only grouped with a few environmental clones, and was distantly affiliated to the new methylotrophic methanogen Methermicoccus shengliensis (highest similarity to pure culture, $86 \%$ ). The KM43T9523 sequence, which groups with the CSG-1 novel lineage, was closely related (98\% similarity) to the environmental clones from tidal flats (Kim et al., 2005) and coastal sediments (Parkes et al., 2007) where methane cycling Archaea also occurred (Figure 2.5). The third cluster groups with the VAL III sequences, a novel lineage distantly related to Methanobacteriales and Methanococcales (Jurgens et al., 2000). The KM43T9502 and KM43T9518 sequences (highest similarity to cultured relative, $76 \%$ ) were related to environmental clones ( $85 \%$ similarity) from mud volcanoes and deep marine sediments where methane also occurred (Heijs et al., 2007; Sorensen and Teske, 2006). As all three lineages were related to methanogens or environmental clones found in methane-bearing environments, and as two were only found active at the highest methane concentrations, we suggest these lineages could be methane cycling Archaea.

\section{SUMMARY}

In Marennes-Oléron Bay, the areas with the highest sedimentation rates and the highest organic matter concentrations harbored kilometer-scale acoustic turbidity zones related to the presence of free methane. In these gassy sediments, the archaeal diversity was dominated by metabolically active methane cycling communities (ANME, methanosarcinales, methanomicrobiales and MBG-B) congruently with the highest methane concentrations. Moreover, metabolically active novel uncultivated lineages, associated to putative methane cycling Archaea, could be specifically associated to methane-bearing sediment habitats. As these lineages are also typical deep subseafloor and methane seep sediment communities, the study of coastal gassy sediments submitted to high environmental and anthropic variables, which modify the microbial niches, would help to define the biogeochemical habitats of the deep biosphere communities.

\section{REFERENCES}


Abegg F , Anderson AL. 1997. The acoustic turbid layer in muddy sediments of Eckernfoerde Bay, Western Baltic: Methane concentration, saturation and bubble characteristics. Marine Geology 137:137-147.

Altschul SF , Gish W, Miller W, Myers EW, Lipman DJ. 1990. Basic local alignment search tool. J Mol Biol 215:403-410.

Bertin X , Chaumillon E. 2005. New insights in shallow gas generation from very high resolution seismic and bathymetric surveys in the Marennes-Oleron Bay, France. Marine Geophysical Researches 26:225-233.

Bertin X , Chaumillon E. 2006. The implication of oyster farming in increasing sedimentation rates in a macrotidal bay: the MarennesOleron Bay, France. Cah. Biol. Mar. 47:1922 .

Bertin X , Chaumillon E, Sottolichio A, Pedreros R. 2005. Tidal inlet response to sediment infilling of the associated bay and possible implications of human activities: the Marennes-Oleron Bay and the Maumusson Inlet, France. Continental Shelf Research 25:1115-1131.

Biddle JF , Lipp JS, Lever MA, Lloyd KG, Sørensen KB, Anderson R, Fredricks HF, Elvert M, Kelly TJ, Schrag DP, Sogin ML, Brenchley JE, Teske A, House CH, Hinrichs K-U. 2006. Heterotrophic Archaea dominate sedimentary subsurface ecosystems off Peru. PNAS 103:3846-3851.

Billeaud I , Chaumillon E, Weber O. 2005. Evidence of a major environmental change recorded in a macrotidal bay (MarennesOleron Bay, France) by correlation between VHR seismic profiles and cores. Geo-Marine Letters 25:1-10.

Boetius A , Ravenschlag K, Schubert CJ, Rickert D, Widdel F, Gieseke A, Amann R, Jørgensen BB, Witte U, Pfannkuche O. 2000. A marine microbial consortium apparently mediating anaerobic oxidation of methane. Nature 407:623-626.

Casamayor EO , Schafer H, Baneras L, PedrosAlio C, Muyzer G. 2000. Identification of and spatio-temporal differences between microbial assemblages from two neighboring sulfurous lakes: comparison by microscopy and denaturing gradient gel electrophoresis. Appl.Environ.Microbiol. 66:499-508.

Cole JR , Chai B, Marsh TL, Farris RJ, Wang Q, Kulam SA, Chandra S, McGarrell DM, Schmidt TM, Garrity GM, Tiedje JM. 2003. The Ribosomal Database Project (RDP-II): previewing a new autoaligner that allows regular updates and the new prokaryotic taxonomy. Nucleic Acids Research 31:442443.

Corinaldesi C , Danovaro R, Dell'Anno A. 2005. Simultaneous recovery of extracellular and intracellular DNA suitable for molecular studies from marine sediments. Applied and Environmental Microbiology 71:46-50.

Damste JSS , Coolen MJL. 2006. Fossil DNA in Cretaceous Black Shales: Myth or Reality? Astrobiology 6:299-302.

Danovaro R , Dell'anno A, Pusceddu A, Fabiano M. 1999. Nucleic acid concentrations (DNA, RNA) in the continental and deep-sea sediments of the eastern Mediterranean: relationships with seasonally varying organic inputs and bacterial dynamics. Deep-Sea Research Part I-Oceanographic Research Papers 46:1077-1094.

Dayhoff MO , Schwartz RM, Orcutt BC. 1978. A model of evolutionary change in proteins. In: Dayhoff MO (ed) Atlas of Protein Sequences and Structure, Vol 5. National Biomedical Research Foundation, Washington DC, p 345-352.

Dell'Anno A , Corinaldesi C. 2004. Degradation and Turnover of Extracellular DNA in Marine Sediments: Ecological and Methodological Considerations. Appl. Environ. Microbiol. 70:4384-4386.

Dell'Anno A , Danovaro R. 2005. Extracellular DNA plays a key role in deep-sea ecosystem functioning. Science 309:2179.

DeLong EF. 1992. Archaea in Coastal Marine Environments. PNAS 89:5685-5689.

Eden PA , Schmidt TM, Blakemore RP, Pace NR. 1991. Phylogenetic Analysis 
of Aquaspirillum-Magnetotacticum Using Polymerase Chain Reaction-Amplified 16s Ribosomal-Rna-Specific DNA. International Journal of Systematic Bacteriology 41:324325 .

Ellermann J , Hedderich R, Bocher R, Thauer RK. 1988. The final step in methane formation. Investigations with highly purified methyl-CoM reductase (component $\mathrm{C}$ ) from Methanobacterium thermoautotrophicum (strain Marburg). European Journal of Biochemistry 172:669-677.

Elshahed MS , Najar FZ, Roe BA, Oren A, Dewers TA, Krumholz LR. 2004. Survey of archaeal diversity reveals an abundance of halophilic Archaea in a low-salt, sulfide- and sulfur-rich spring. Appl Environ Microbiol 70:2230-2239.

Excoffier L , Laval G, Schneider S. 2005. Arlequin ver. 3.0: An integrated software package for population genetics data analysis. Evolutionary Bioinformatics Online 1:47-50.

Fleischer P , Orsi TH, Richardson MD, Anderson AL. 2001. Distribution of free gas in marine sediments: a global overview. GeoMarine Letters 21:103-122.

Froidefond JM , Jegou AM, Hermida J, Lazure P, Castaing P. 1998. Variability of the Gironde turbid plume by remote sensing. Effects of climatic factors. Oceanol. Acta 21:191-207.

Galtier N , Gouy M, Gautier C. 1996. SEAVIEW and PHYLO-WIN: two graphic tools for sequence alignment and molecular phylogeny. Comput Appl Biosci 12:543-548.

Girguis PR , Cozen AE, DeLong EF. 2005. Growth and population dynamics of anaerobic methane-oxidizing Archaea and sulfatereducing Bacteria in a continuous-flow bioreactor. Appl Environ Microbiol 71:37253733 .

Good IJ. 1953. The Population Frequencies of Species and the Estimation of Population Parameters. Biometrika 40:237-264.

Gouleau D , Jouanneau JM, Weber O, Sauriau PG. 2000. Short- and long-term sedimenta- tion on Montportail-Brouage intertidal mudflat, Marennes-Oleron Bay (France). Continental Shelf Research 20:1513-1530.

Hales BA , Edwards C, Ritchie DA, Hall G, Pickup RW, Saunders JR. 1996. Isolation and identification of methanogen-specific DNA from blanket bog peat by PCR amplification and sequence analysis. Appl. Environ. Microbiol. 62:668-675.

Hall TA. 1999. BioEdit: a user-friendly biological sequence alignment editor and analysis program for Windows 95/98/NT. Nucl. Acids. Symp. Ser. 41:95-98.

Hallam SJ , Girguis PR, Preston CM, Richardson PM, DeLong EF. 2003. Identification of methyl coenzyme $\mathrm{M}$ reductase $\mathrm{A}(\mathrm{mcr} A)$ genes associated with methane-oxidizing $A r$ chaea. Appl Environ Microbiol 69:54835491.

Hallam SJ , Putnam N, Preston CM, Detter JC, Rokhsar D, Richardson PM, DeLong EF. 2004. Reverse methanogenesis: testing the hypothesis with environmental genomics. Science 305:1457-1462.

Hamilton EL. 1972. Compressional-wave attenuation in marine sediments. Geophysics $37: 620-646$.

Heijs SK , Haese RR, van der Wielen PW, Forney LJ, van Elsas JD. 2007. Use of $16 \mathrm{~S}$ rRNA gene based clone libraries to assess microbial communities potentially involved in anaerobic methane oxidation in a Mediterranean cold seep. Microb Ecol 53:384-398.

Hensen C , Nuzzo M, Hornibrook E, Pinheiro LM, Bock B, Magalhaes VH, Bruckmann W. 2007. Sources of mud volcano fluids in the Gulf of Cadiz - indications for hydrothermal imprint. Geochimica Et Cosmochimica Acta 71:1232-1248.

Hinrichs KU , Hayes JM, Sylva SP, Brewer PG, DeLong EF. 1999. Methane-consuming Archaebacteria in marine sediments. Nature 398:802-805.

Hovland M , Judd AG, Burke RA. 1993. The global flux of methane from shallow submarine sediments. Chemosphere 26:559-578. 
Inagaki F , Kuypers MM, Tsunogai U, Ishibashi J, Nakamura K, Treude T, Ohkubo S, Nakaseama M, Gena K, Chiba H, Hirayama H, Nunoura T, Takai K, Jørgensen BB, Horikoshi K, Boetius A. 2006a. Microbial community in a sediment-hosted $\mathrm{CO} 2$ lake of the southern Okinawa Trough hydrothermal system. Proc Natl Acad Sci U S A 103:14164-14169.

Inagaki F , Nunoura T, Nakagawa S, Teske A, Lever M, Lauer A, Suzuki M, Takai K, Delwiche M, Colwell FS, Nealson KH, Horikoshi K, D'Hondt S, Jørgensen BB. 2006b. Biogeographical distribution and diversity of microbes in methane hydrate-bearing deep marine sediments on the Pacific Ocean Margin. Proc Natl Acad Sci USA 103:2815-2820.

Inagaki F , Okada H, Tsapin AI, Nealson KH. 2005. The paleome: a sedimentary genetic record of past microbial communities. Astrobiology 5:141-153.

Iversen N , Jørgensen BB. 1985. Anaerobic Methane Oxidation Rates at the SulfateMethane Transition in Marine Sediments from Kattegat and Skagerrak (Denmark). Limnology and Oceanography 30:944-955.

Juniper SK , Cambon MA, Lesongeur F, Barbier G. 2001. Extraction and purification of DNA from organic rich subsurface sediments (ODP Leg 169S). Marine Geology 174:241247.

Juottonen H, Galand PE, Yrjala K. 2006. Detection of methanogenic Archaea in peat: comparison of PCR primers targeting the mcrA gene. Res Microbiol 157:914-921.

Jurgens G , Glockner F, Amann R, Saano A, Montonen L, Likolammi M, Munster U. 2000. Identification of novel Archaea in bacterioplankton of a boreal forest lake by phylogenetic analysis and fluorescent in situ hybridization(1). FEMS Microbiol Ecol 34:4556 .

Kemp PF , Lee S, Laroche J. 1993. Estimating the Growth Rate of Slowly Growing Marine Bacteria from RNA Content. Appl Environ Microbiol 59:2594-2601.
Kendall MM , Wardlaw GD, Tang CF, Bonin AS, Liu Y, Valentine DL. 2007. Diversity of Archaea in marine sediments from Skan Bay, Alaska, including cultivated methanogens, and description of Methanogenium boonei sp. nov. Appl Environ Microbiol 73:407414.

Kerkhof L , Ward BB. 1993. Comparison of Nucleic Acid Hybridization and Fluorometry for Measurement of the Relationship between RNA/DNA Ratio and Growth Rate in a Marine Bacterium. Appl Environ Microbiol 59:1303-1309.

Kim BS , Oh HM, Kang H, Chun J. 2005. Archaeal diversity in tidal flat sediment as revealed by $16 \mathrm{~S}$ rDNA analysis. J Microbiol 43:144-151.

Knittel K , Losekann T, Boetius A, Kort R, Amann R. 2005. Diversity and distribution of methanotrophic Archaea at cold seeps. Appl Environ Microbiol 71:467-479.

Kolb B. 1999. Headspace sampling with capillary columns. Journal of Chromatography A 842:163-205.

Kramer JG , Singleton FL. 1993. Measurement of rRNA Variations in Natural Communities of Microorganisms on the Southeastern U.S. Continental Shelf. Appl Environ Microbiol 59:2430-2436.

Kvenvolden KA. 1988. Methane hydrate: a major reservoir of carbon in the shallow geosphere? Chemical Geology 71:41-51.

Lloyd KG , Lapham L, Teske A. 2006. An anaerobic methane-oxidizing community of ANME-1b Archaea in hypersaline Gulf of Mexico sediments. Appl Environ Microbiol 72:7218-7230.

Luton PE, Wayne JM, Sharp RJ, Riley PW. 2002. The $m c r A$ gene as an alternative to $16 \mathrm{~S}$ rRNA in the phylogenetic analysis of methanogen populations in landfill. Microbiology 148:3521-3530.

Ma K , Liu XL, Dong XZ. 2006. Methanosaeta harundinacea sp nov., a novel acetatescavenging methanogen isolated from a UASB reactor. International journal of systematic and evolutionary microbiology 56:127-131. 
Martin AP. 2002. Phylogenetic approaches for describing and comparing the diversity of microbial communities. Applied and Environmental Microbiology 68:3673-3682.

Migeon S , Weber O, Faugeres JC, Saint-Paul J. 1999. SCOPIX: A new X-ray imaging system for care analysis. Geo-Marine Letters 18:251-255.

Nauhaus K , Albrecht M, Elvert M, Boetius A, Widdel F. 2007. In vitro cell growth of marine archaeal-bacterial consortia during anaerobic oxidation of methane with sulfate. Environ Microbiol 9:187-196.

Nauhaus K , Boetius A, Kruger M, Widdel F. 2002. In vitro demonstration of anaerobic oxidation of methane coupled to sulphate reduction in sediment from a marine gas hydrate area. Environ.Microbiol. 4:296-305.

Nauhaus K , Treude T, Boetius A, Kruger M. 2005. Environmental regulation of the anaerobic oxidation of methane: a comparison of ANME-I and ANME-II communities. Environ Microbiol 7:98-106.

Nicol GW , Glover LA, Prosser JI. 2003. The impact of grassland management on archaeal community structure in upland pasture rhizosphere soil. Environ.Microbiol. 5:152-162.

Niemann H , Losekann T, de Beer D, Elvert M, Nadalig T, Knittel K, Amann R, Sauter EJ, Schluter M, Klages M, Foucher JP, Boetius A. 2006. Novel microbial communities of the Haakon Mosby mud volcano and their role as a methane sink. Nature 443:854-858.

Nunoura T , Oida H, Toki T, Ashi J, Takai K, Horikoshi K. 2006. Quantification of mcrA by quantitative fluorescent PCR in sediments from methane seep of the Nankai Trough. FEMS Microbiol Ecol 57:149-157.

Orcutt B , Boetius A, Elvert M, Samarkin V, Joye SB. 2005. Molecular biogeochemistry of sulfate reduction, methanogenesis and the anaerobic oxidation of methane at Gulf of Mexico cold seeps. Geochimica Et Cosmochimica Acta 69:4267-4281.

Orphan VJ , Christopher H, House K-U, Hinrichs KD, McKeegan E, DeLong F. 2002.
Multiple archaeal groups mediate methane oxidation in anoxic cold seep sediments. PNAS 99:7663-7668.

Orphan VJ , Hinrichs KU, Ussler W, Paull CK, Taylor LT, Sylva SP, Hayes JM, Delong EF. 2001a. Comparative Analysis of Methane-Oxidizing Archaea and SulfateReducing Bacteria in Anoxic Marine Sediments. Applied and Environmental Microbiology 67:1922-1934.

Orphan VJ , House CH, Hinrichs KU, McKeegan KD, Delong DF. 2001b. Methaneconsuming Archaea revealed by directly coupled isotopic and phylogenetic analysis. Science 293:484-487.

Parkes RJ , Cragg BA, Banning N, Brock F, Webster G, Fry JC, Hornibrook E, Pancost RD, Kelly S, Knab N, Jørgensen BB, Rinna J, Weightman AJ. 2007. Biogeochemistry and biodiversity of methane cycling in subsurface marine sediments (Skagerrak, Denmark). Environ Microbiol 9:1146-1161.

Parkes RJ , Webster G, Cragg BA, Weightman AJ, Newberry CJ, Ferdelman TG, Kallmeyer J, Jørgensen BB, Aiello IW, Fry JC. 2005. Deep sub-seafloor prokaryotes stimulated at interfaces over geological time. Nature 436:390-394.

Polz MF , Cavanaugh CM. 1998. Bias in template-to-product ratios in multitemplate PCR. Appl Environ Microbiol 64:3724-3730.

Purdy KJ , Munson MA, Nedwell DB, Embley TM. 2002. Comparison of the molecular diversity of the methanogenic community at the brackish and marine ends of a UK estuary. Fems Microbiology Ecology 39:17-21.

Purdy KJ , Nedwell DB, Embley TM. 2003. Analysis of the sulfate-reducing bacterial and methanogenic archaeal populations in contrasting Antarctic sediments. Appl Environ Microbiol 69:3181-3191.

Raymond M , Rousset F. 1995. An exact test for population differentiation. Evolution 49:1280-1283.

Reeburgh WS. 2007. Oceanic methane biogeochemistry. Chem Rev 107:486-513. 
Results: from the coast to the Mid-ocean ridges

Reeve JN , Nolling J, Morgan RM, Smith DR. 1997. Methanogenesis: genes, genomes, and who's on first? J Bacteriol 179:5975-5986.

Riera P , Richard P. 1996. Isotopic determination of food sources of Crassostrea gigas along a trophic gradient in the estuarine bay of Marennes-Oleron. Estuarine Coastal and Shelf Science 42:347-360.

Sackett WM. 1964. The depositional history and isotopic organic carbon composition of marine sediments. Marine Geology 2:173185.

Saitou N , Nei M. 1987. The neighbor-joining method: a new method for reconstructing phylogenetic trees. Mol Biol Evol 4:406-425.

Schloss PD , Handelsman J. 2004. Status of the microbial census. Microbiol Mol Biol Rev 68:686-691.

Schloss PD , Handelsman J. 2005. Introducing DOTUR, a computer program for defining operational taxonomic units and estimating species richness. Appl Environ Microbiol 71:1501-1506.

Schloss PD , Handelsman J. 2006. Introducing SONS, a tool for operational taxonomic unit-based comparisons of microbial community memberships and structures. Appl Environ Microbiol 72:6773-6779.

Singleton DR , Furlong MA, Rathbun SL, Whitman WB. 2001. Quantitative comparisons of $16 \mathrm{~S}$ rRNA gene sequence libraries from environmental samples. Appl Environ Microbiol 67:4374-4376.

Sørensen KB , Teske A. 2006. Stratified communities of active Archaea in deep marine subsurface sediments. Appl Environ Microbiol 72:4596-4603.

Springer E , Sachs MS, Woese CR, Boone DR. 1995. Partial gene sequences for the A subunit of methyl-coenzyme $\mathrm{M}$ reductase ( $m c r I)$ as a phylogenetic tool for the family Methanosarcinaceae. Int J Syst Bacteriol 45:554-559.

Suzuki MT , Giovannoni SJ. 1996. Bias caused by template annealing in the amplification of mixtures of $16 \mathrm{~S}$ rRNA genes by PCR. Appl Environ Microbiol 62:625-630.
Takai K , Horikoshi K. 1999. Genetic diversity of Archaea in deep-sea hydrothermal vent environments. Genetics 152:1285-1297.

Teske A , Sørensen KB. 2008. Uncultured Archaea in deep marine subsurface sediments: have we caught them all? ISME J 2:3-18.

Thiessen O , Schmidt M, Theilen F, Schmitt M, Klein G. 2006. Methane formation and distribution of acoustic turbidity in organicrich surface sediments in the Arkona Basin, Baltic Sea. Continental Shelf Research 26:2469-2483.

Thompson JD , Higgins DG, Gibson TJ. 1994. CLUSTAL W: improving the sensitivity of progressive multiple sequence alignment through sequence weighting, positionspecific gap penalties and weight matrix choice. Nucleic Acids Res 22:4673-4680.

Thomsen TR, Finster K, Ramsing NB. 2001. Biogeochemical and molecular signatures of anaerobic methane oxidation in a marine sediment. Appl Environ Microbiol 67:16461656 .

Treude T , Knittel K, Blumenberg M, Seifert R, Boetius A. 2005a. Subsurface microbial methanotrophic mats in the Black Sea. Appl Environ Microbiol 71:6375-6378.

Treude T , Kruger M, Boetius A, Jørgensen BB. 2005b. Environmental control on anaerobic oxidation of methane in the gassy sediments of Eckernforde Bay (German Baltic). Limnology and Oceanography 50:1771-1786.

Valentine DL. 2002. Biogeochemistry and microbial ecology of methane oxidation in anoxic environments: a review. Antonie Van Leeuwenhoek 81:271-282.

Valentine DL , Chidthaisong A, Rice A, Reeburgh WS, Tyler SC. 2004. Carbon and hydrogen isotope fractionation by moderately thermophilic methanogens. Geochimica Et Cosmochimica Acta 68:1571-1590.

Valentine DL , Reeburgh WS. 2000. New perspectives on anaerobic methane oxidation. Environ Microbiol 2:477-484. 
Webster G , Newberry CJ, Fry JC, Weightman AJ. 2003. Assessment of bacterial community structure in the deep sub-seafloor biosphere by $16 \mathrm{~S}$ rDNA-based techniques: a cautionary tale. J. Microbiol. Methods $55: 155-164$.

Wilms R , Sass H, Kopke B, Cypionka H, Engelen B. 2007. Methane and sulfate profiles within the subsurface of a tidal flat are reflected by the distribution of sulfatereducing Bacteria and methanogenic Archaea. FEMS Microbiol Ecol 59:611-621.

Wolfe RS. 1971. Microbial formation of methane. Adv Microb Physiol 6:107-146.

Zellner G , Boone DR, Keswani J, Whitman WB, Woese CR, Hagelstein A, Tindall BJ, Stackebrandt E. 1999. Reclassification of Methanogenium tationis and Methanogenium liminatans as Methanofollis tationis gen. nov., comb. nov. and Methanofollis liminatans comb. nov. and description of a new strain of Methanofollis liminatans. International Journal of Systematic Bacteriology 49:247-255. 